Historic, archived document

Do not assume content reflects current scientific knowledge, policies, or practices. 



\section{MARKETING MARGINS FOR FRUITS AND VEGETABLES}

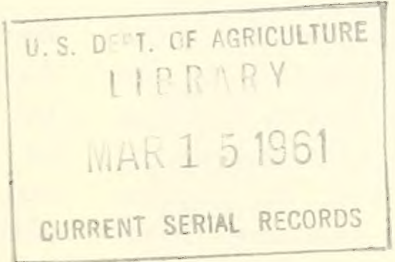

Reprinted From

The Marketing and Transportation Situotion January 1961

U. S. DEPARTMENT OF AGRICULTURE Agricultural Marketing Service Marketing Economics Research Division

AMS-298(1961)

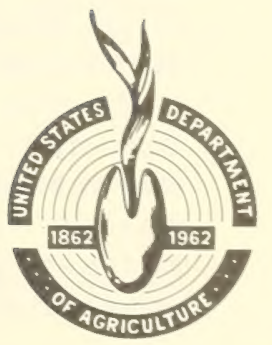


Marketing margins for fresh fruits and vegetables, together with :
$:$ retail and grower prices, were higher in 1960 than in 1959. Mar- :
$:$ keting margins increased 4 percent; retail prices averaged about :
$: 8$ percent higher; and prices received by growers were up about $15:$
$:$ percent. Much of the increase at both grower and retail levels re-
$:$ sulted from higher prices for apples, oranges, and potatoes. Retail :
$:$ prices of processed products declined 4 percent, reflecting mainly :
$:$ reductions in returns to growers. Marketing charges were about :
$:$ the same in both years.

Fresh Fruits and Vegetables

The retail cost of the fresh fruits in the family market basket increased to an annual rate of $\$ 144$ in 1960 from $\$ 133$ in 1959 (table 19)。 2/ About two-thirds of this increase was reflected in higher prices received by farmers and one-third in higher marketing charges. Increases in 1960 followed decreases in 1959. The farmer's share of the retail cost of fresh fruits and vegetables increased to 37 percent in 1960, up from 34 percent in 1959.

Sharp price increases in potatoes, apples, and oranges at both farm and retail levels accounted for much of the increase in the retail cost and farm value of the fresh fruits and vegetables in the market basket. The retail price of potatoes jumped from an average of 63.3 cents per 10 pounds in 1959 to 71.7 cents in 1960; the farm value rose from 19.2 cents to 24.5 cents, and the marketing margin from 44.1 cents to 47.2 cents. Stocks of potatoes on Jan uary 1, 1960, were 10 percent smaller than a year earlier as a result of a smaller late potato crop in 1959 than in 1958. Further, the production of potatoes for harvest during the winter months was much smaller in 1960 than in 1959 because of reduced acreage and severe damage by cold weather. Prices received by farmers were higher in 1960 than in 1959 in each month except June, particularly in the early months of the year, although the spring, summer, and fall crops were larger in 1960 than in 1959 。

For the quantity of apples equivalent to a pound at retail, farmers received an average of 5.4 cents in 1960 , compared with 4.0 cents in 1959. The gain at the retail level was larger, since the farmretail spread increased from 10.2 cents to 10.8 cents. Stocks of apples were lighter on January 1, 1960, than a year earlier, and the 1960 crop was 5 percent smaller than average and 13 percent smaller than the 1959 production.

In the first half of 1960 , grower prices for Florida oranges were lower, California oranges higher, than for the same period a year earlier. United States ayerage prices of fresh oranges both at grower and retail levels were higher in most months of 1960 than a year earlier. The annual average retail price rose from 66.4 cents a dozen, in 1959 to 75.6 cents

1/ Prepared by Victor V. Bowman, agricultural economist, Marketing Economics Research Division, Agricultural Marketing Service.

2/ The family market basket contains the average quantities of fruits, vegetables, and other domestically produced farm food products bought by the typical urban wageearner or clerical-worker family in 1952. The farm value of a food in the market basket is the payment the farmer receives for its farm product equivalent. The marketing margin or spread between the retail cost and farm value is the charge for marketing services. 
in 1960. The marketing margin went up from 44.3 to 48.3 cents; so growers received more than half the gain in retail prices. The volume of oranges sold fresh from the 1959-60 crop was smaller than that from the 1958-59 crop, largely be cause the California Navel and Valencia crops were short. Prices in the final quarter of the year were strengthened by reduced marketings from the 1960-61 crop. Shipments from Florida were late in starting and increased slower than usual; the California crop was light again。

\section{Processed Fruits and Vegetables}

Total marketing charges for processed fruits and vegetables in the family market basket were about the same in 1960 as in 1959 (table 19). The total farm value of these products declined 14 percent, accompanied by a 3 percent reduction in the retail cost.

Lower prices for canned orange juice and frozen juice concentrate accounted for much of the reduction in the retail cost of the processed products. Similarly much of the decrease in the farm value resulted from a sharp drop from 1959 to 1960 in prices received by growers for oranges for processing. The bulk of the processed products sold to consumers in 1960 were processed from 1959-60 Florida oranges. Prices received by growers for the 1959-60 crop were considerably lower than those for the 1958 59 crop。

\section{Marketing Margins for Oranges}

Grower-retail marketing spreads have been analyzed for Florida fresh oranges sold in Atlanta, Chicago, Detroit, New York and Pittsburgh, for California fresh oranges marketed in New York and Chicago, and for canned orange juice and frozen orange juice retailed in New York and Chicago.

Florida Fresh Oranges

Retail prices of Florida oranges marketed in five large eastern and middle western cities during the 1959-60 season varied from $\$ 7.57$ per 90 -pound box in Atlanta to $\$ 9.66$ in New York (table 20). 3/ Prices at all market levels were lower in 1959-60 than in the previous season.

Spreads between retail prices and reo turns to the grower ("on-tree" returns) in 1959-60 ranged from $\$ 5.92$ in Atlanta to $\$ 7.16$ in Detroit (table 20). As per. centages of retail prices, these spreads, or marketing margins, ranged from 74 percent in New York to 80 percent in Pittsburgh. In each of the five cities ex- cept Pittsburgh, marketing margins decreased from 1958.59 to 1959-60, along with prices at retail and other market levels. Though marketing margins declined, decreases were not proportionate to reductions in retail prices, so marketing margins relative to retail prices increased from 1958-59 to 1959-60.

Returns to growers in 1959-60 varied from $\$ 1.65$ per 90 pounds of oranges shipped to Atlanta to $\$ 2.55$ for those marketed in New York. As percentages of retail prices, returns to growers varied from 20 percent for Pittsburgh shipments to 26 percent for New York shipments.

Differences in quality of fruit may explain part of the variation in on-tree returns from oranges shipped to different destinations. Thus, New York, for which retail prices and onotree returns were highest, received fruit of a better average quality than most other cities.

The drop in prices at all market levels 
Table 19.--Fruits and vegetables: Retail cost, farm value, marketing margin, and farmer's share of retail cost, annual, 1956-60 $\underline{1}^{\prime}$

Fresh fruits and vegetables

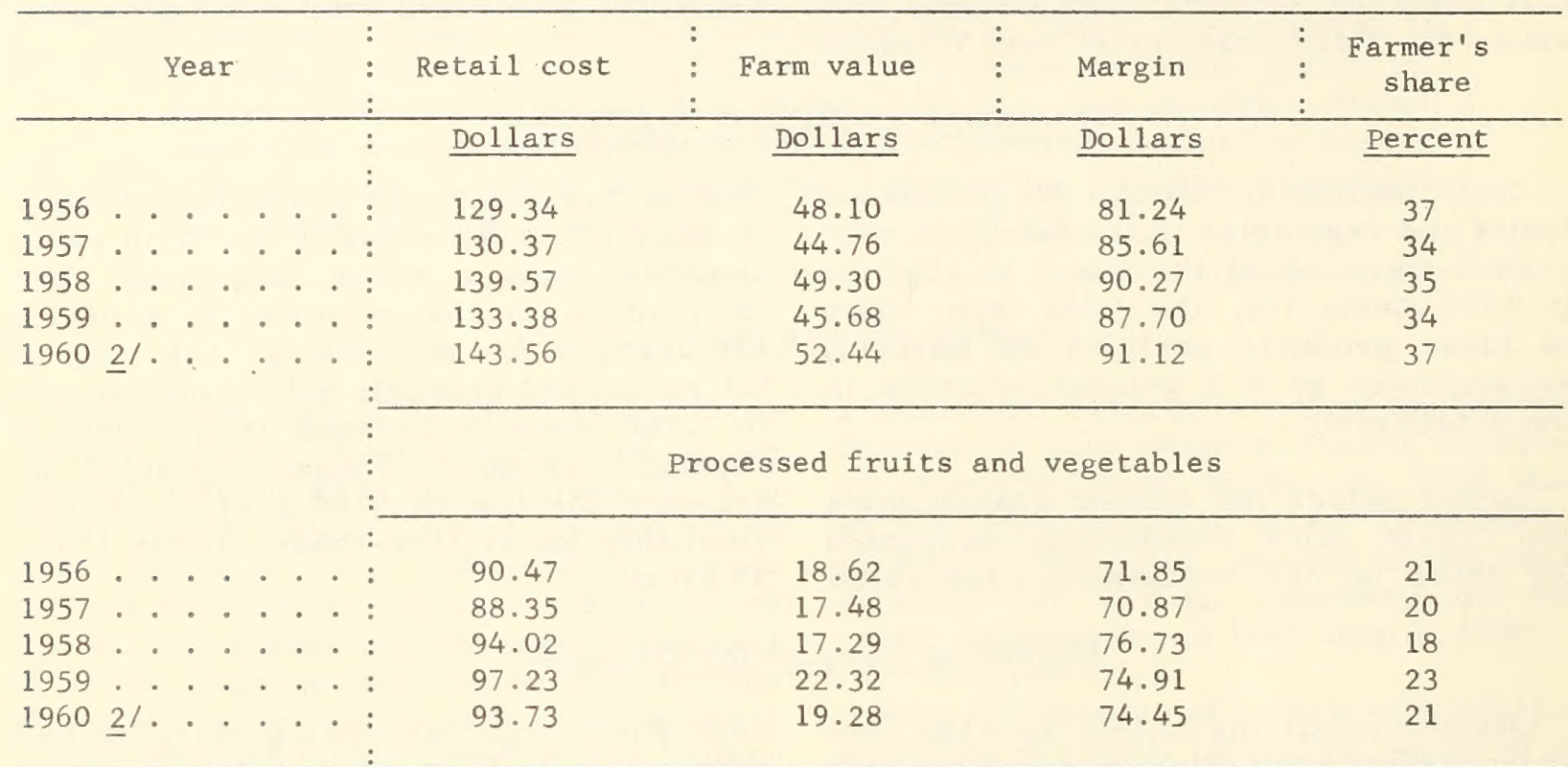

1/ Data are for quantities of fruits and vegetables bought for consumption at home per urban wage-earner or clerical-worker family in 1952.

2/ Preliminary.

from 1958-59 to $1959-60$ resulted from an increase in the supply of Florida fresh oranges. Shipments in the 1958-59 season were the smallest in a generation and prices were the highest. The crop was lighter than other recent crops and a smaller proportion was marketed as fresh fruit. The 1959-60 crop was larger and a greater proportion was marketed fresh. Sales of California fresh oranges, however, declined sharply from 1958-59 to $1959-60$.

Charges for retailing and wholesaling are the largest segment of the total marketing margin. As a percentage of the retail price, the combined wholesaleretail margin in 1958-59 varied from 33 percent in Chicago to 45 percent in Detroit; in 1959-60, from 37 percent in Chicago to 46 percent in Atlanta. Dollarand-cents wholesale-retail margins in both seasons were largest in New York and Detroit, where retail prices were highest; margins were smallest in Chi- cago and Pittsburgh, where prices were near the lowest. The lowest retail price was in Atlanta in both seasons. Transportation costs to Atlanta were the lowest, but the wholesale-retail margin was the third largest among the five cities in both years. Wholesale-retail margins in each of the cities, except Pittsburgh, averaged lower in the 1959-60 season than a year earlier.

Retail store margins vary among cities, depending on pricing policies, operating costs, and many other factors. Variations in services performed by wholesalers affect their margins. For fresh fruits and vegetables, these margins tend to vary directly with changes in prices of the product. Thus, the wholesale retail margin in all but one of thesecities decreased from 1958-59 to 1959-60 when prices of oranges at all marketing levels decreased.

Charges for marketing services pera 


$$
-40-
$$

Table 20.--Florida Oranges: Retail prices, marketing margins, and on-tree returns per 90-pound box, 1958-59 and 1959-60

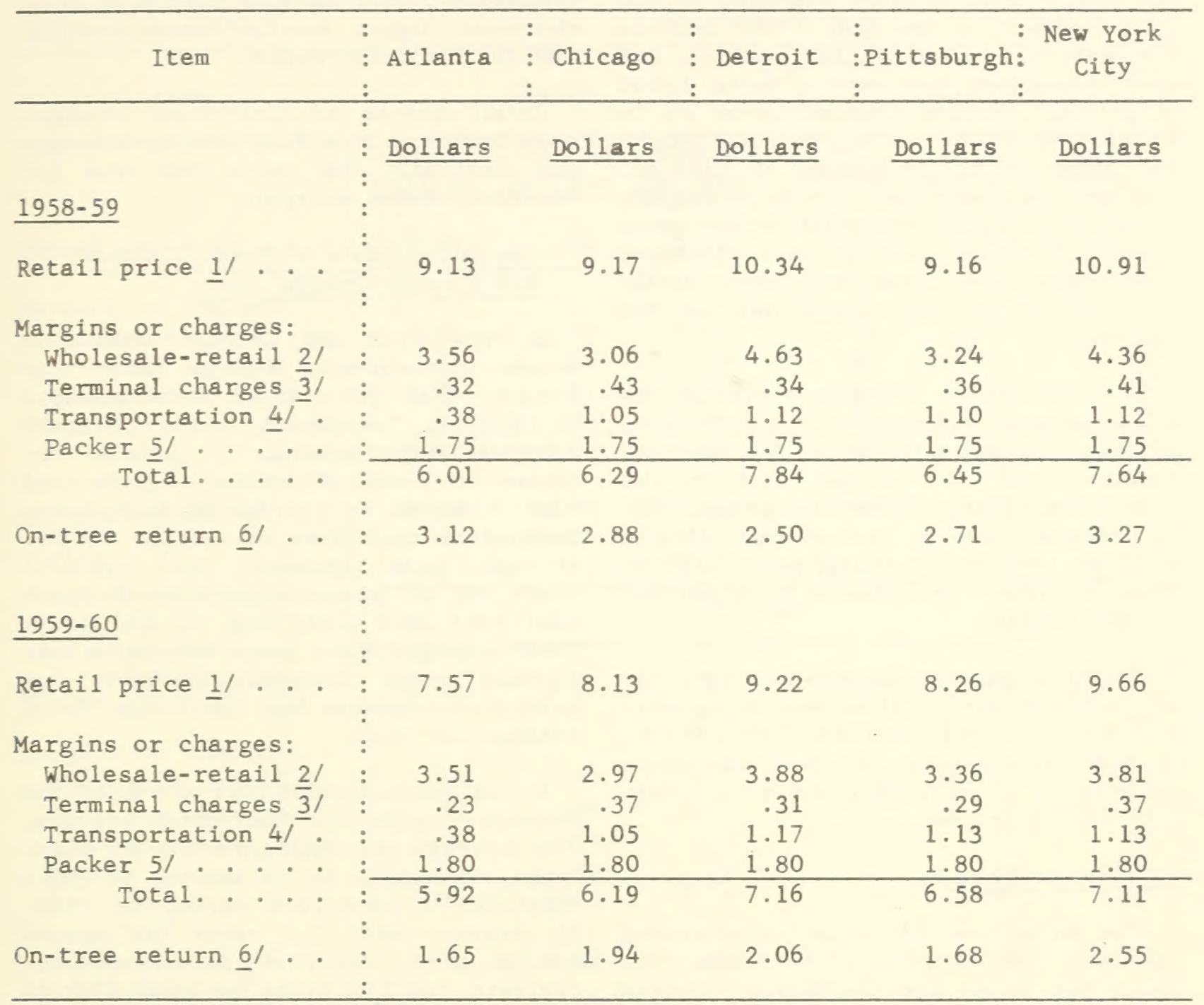

1/ Calculated from retail prices collected by the Bureau of Labor Statistics; 3 percent allowance for waste and spoilage. Average of monthly prices during marketing season November - May.

2/ Retail prices less average auction or wholesale price for the week preceeding that in which the BLS collected prices. Margins include terminal cartage charges.

3/ Auction and brokerage commissions and miscellaneous charges.

4/ Weighted average truck and rail freight and refrigeration charges.

5/ Weighted average of cost of packing in the three most commonly used containers. Includes picking, hauling, selling, and advertising costs; data for 1959-60 season are preliminary.

6/ Retail price less total marketing margin. 
formed in the producing areas accounted for the second largest segment of the total marketing margin. They include the costs of picking, hauling, packing, and advertising and other selling costs. Local marketing charges varied from 16 to 19 percent of the retail price in 1958-59 and from 19 to 24 percent in 1959-60。 Charges in cents per box were slightly higher in 1959.60 and retail prices were lower. Average packing and container costs have risen in recent years, partly because of the increased use of the half-box.

Transportation charges made up the third largest segment of the marketing margin. As proportions of the average retail prices of oranges sold in the five cities, transportation charges in 1958 59 ranged from 4 percent for Atlanta to 12 percent for Pittsburgh and in 1959.60 from 5 percent for Atlanta to 14 percent for Pittsburgh.

Terminal market charges accounted for the smallest portion of the marketing mar gin. They declined from 1958-59 to 1959-60 in line with prices, as they are made up largely of commissions which vary with selling prices.

\section{California Oranges}

The division of the retail price among growers and marketing functions was about the same for California oranges retailed in New York and Chicago as for Florida oranges sold in these cities. During the California Navel seasons $1956=$ 57 through 1958-59 and the Valencia seasons 1957 through 1959, the wholesaleretail margin accounted for about 34 to 47 percent of retail prices, producingarea marketing charges for about 13 to 16 percent, transportation charges also from 13 to 16 percent, terminal market changes for about 5 percent, and the grower's on-tree returns for 21 to 31 percent (table 21)。 Retail prices were higher for California than for Florida oranges marketed in New York and Chicago. In New York during the 1958-59 season, retail prices of Florida oranges averaged about 70 percent of those for
California oranges, Dollars-and-cents wholesale-retail margins also were considerably higher for California oranges than for Florida oranges.

Retail prices of California oranges were higher in New York than in Chicago, and generally the same was true for wholesale-retail margins.

Comparative Costs of Fresh, Canned, and Frozen Orange Juice

In New York and Chicago canned or frozen concentrated orange juice was cheaper than juice from fresh oranges in 1958-59. The quantity of Florida fresh oranges (approximately 3 pounds) res quired to yield 24 ounces of juice cost New Yorkers an average of 36.4 cents. Equivalent quantities of canned single. strength juice (24-ounce can) cost 23.1 cents and of frozen concentrate (6-ounce can) cost 25.4 cents (fig。 8). California fresh oranges were more expensive than Florida fresh oranges. Probably few eastern consumers buy California Navel oranges for juice.

It cost considerably less to market the processed products than fresh oranges. The average marketing margin for quantities equivalent to 24 ounces of juice marketed in New York during the 195859 season was 13.5 cents for canned orange juice, 15.8 cents for frozen concentrate, and 25.1 cents for fresh Florida oranges. The marketing marginaccounted for about 70 percent of the retail price of fresh oranges and about 60 percent of the retail prices of canned juice and frozen concentrate.

Among the various segments of the total marketing margin, the biggest differences were for wholesaling and retailing. The combined wholesale-retail margin for Florida fresh oranges in New York was five times that for canned juice. The higher costs of handling fresh oranges, which are more perishable and bulky than the processed products, account for the big differences in these margins. Transportation charges also were considerably higher for fresh 
Table 21.--California Oranges, Navel and Valencia: Retail prices, marketing

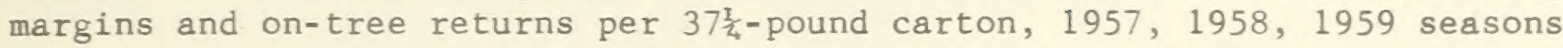

New York City

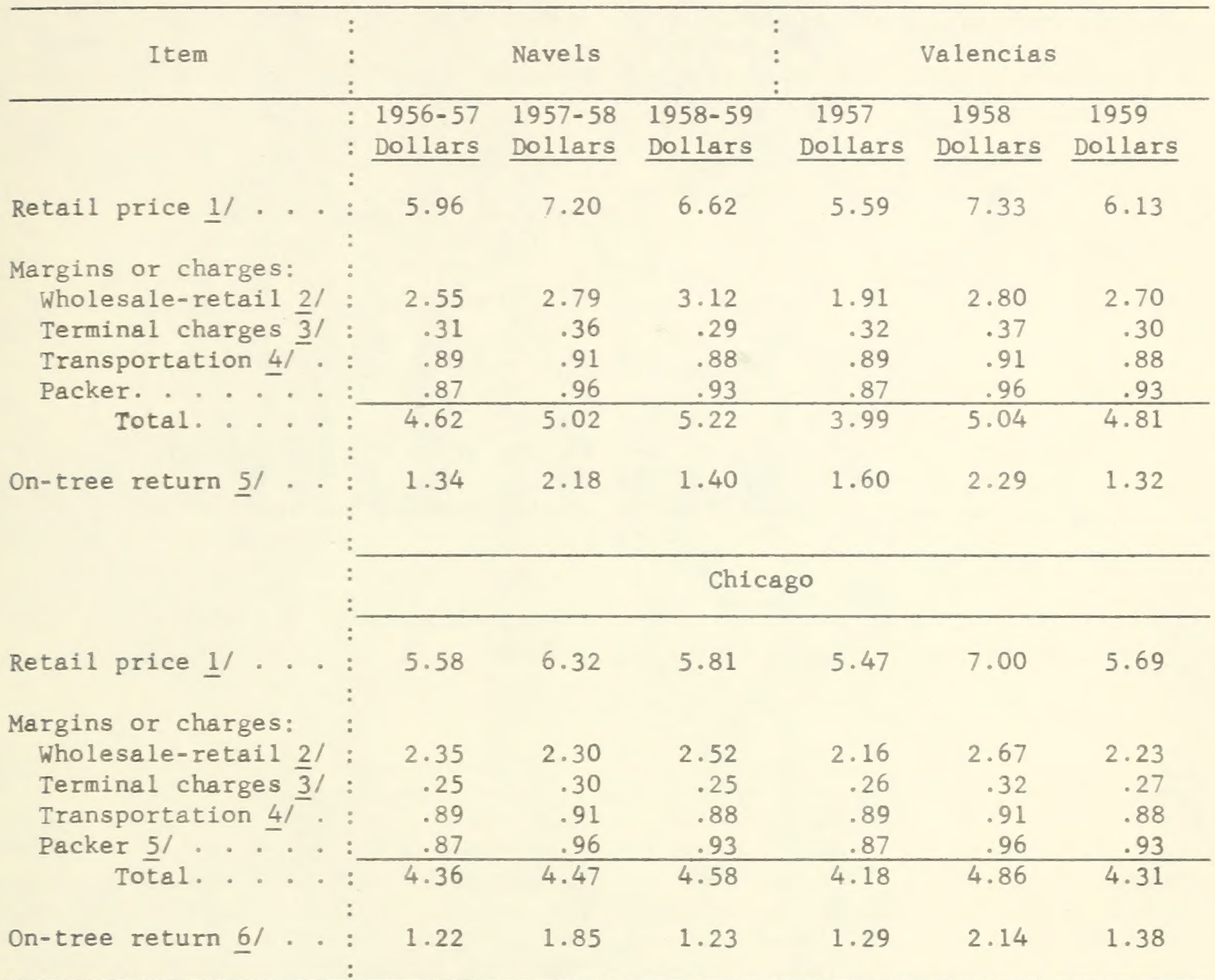

I/ Calculated from retail prices collected by the Bureau of Labor Statistics; 3 percent allowance for waste and spoilage. Average of monthly prices during marketing season: Navels, December-May; Valencias, June-November.

2/ Retail prices less average auction price for the week preceeding that in which the BLS collected prices. Margins include terminal cartage charges.

3/ Auction and brokerage commissions and miscellaneous charges.

4/ Rail freight and standard refrigeration.

5/ Includes picking, hauling, packing, selling and advertising costs.

6/ Retail price less total marketing margin. 


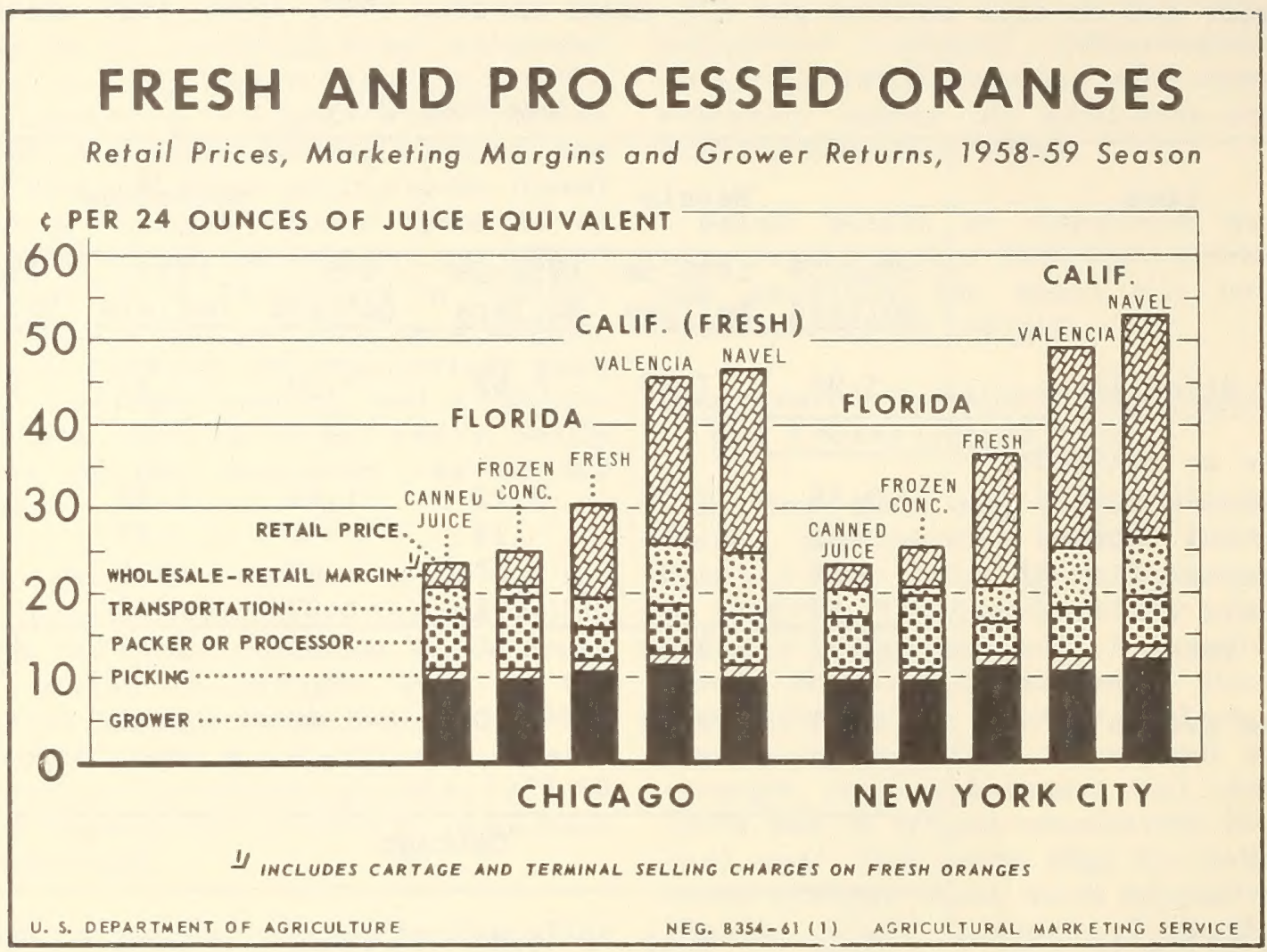

Figure 8

oranges than for equivalent quantities of the processed products, principally because of differences in weight. Shipping charges for Florida oranges were nearly five times those for frozen concentrate. Charges for processing canned juice and frozen concentrate, however, exceeded packing and other local marketing charges for fresh oranges. The processing margin for frozen concentrate was more than twice packing charges for
Florida fresh oranges.

Returns to Florida growers derived from retail prices in New York and Chicago during the 1958-59 marketing season were higher for fresh oranges than for oranges for processing. For the entire 1958-59 crop, however, prices received by Florida growers averaged higher for oranges for processing than those for fresh use. 